\section{CLIMATE JUSTICE IS WHAT'S NEEDED FOR COPENHAGEN SUCCESS}

In light of the established scientific consensus there is little doubt that the current climate crisis is anthropogenic as opposed to what Sarah Palin tried to sell to the world during the last US presidential election not long ago! When we see the rapid melting of the North-Pole glaciers, sealevel rising, repetitious flooding in all parts of the world, food shortages, drought and cyclone hitting everywhere in a vicious cycle affecting millions - it is clear that our mother nature returns to us in revenge with a vengeance again and again. We should wake up and do something for our own good and for our posterity. The whole world is now pinning its hope on the forthcoming Copenhagen meeting of the world leaders on the climate change issues in December this year. The big question remains whether they will be able to do something great if they do not have "the right political will." They must have it here and now. The world cannot wait any more, it is now or never!

A successful international climate agreement cannot be ironed out at Copenhagen without the wider participation of the developing countries. It is no less worrying that the developing countries will account for more than half of global emissions by the year 2020. China turned out to be the world's largest CO2 emitter in 2006 surpassing the United States. The United States and other developed countries should take the lead and bring the key emerging economies: China, India, Brazil and Mexico under their wings.

However, it will not be easy to make the developing countries cut their emissions as their economic development and growth depend on it. With the developed countries' burden of sharing historical guilt for the majority of the current stock of anthropogenic greenhouse gases in the atmosphere that have caused the global warming, some fair mechanisms for climate mitigation and adaptation have to be urgently invented to give us a better and safer planet to live in. Some formulaic approaches to the UNFCCC principle of "common but differentiated responsibilities and respective capabilities" need to be devised to strike the balance between the developing countries' right to economic development and their obligation for mitigation of climate change.

Whatever mechanisms are devised in the proposed international climate agreement have to be based on the principles of fairness and justice, otherwise the success of a global deal in Copenhagen will be a far way off. Both developed and developing countries must act in good faith towards the common goal. There are reasons why the developing countries have already lost their faith in the developed countries' campaign for the former to cut their emissions. First, the developing countries feel that carbon emissions offered the developed countries the ladder to economic prosperity, and now when it comes to the developing countries they tend to kick it away from them.

\section{Articles}

The EU and human rights: an unlikely evolution

The general partnership in German law

Institute News

\section{Articles (cont'd)}

Genocide, crimes against humanity and war crimes: can they be pardoned or amnestied?

Prosecuting terrorism: the Old Bailey versus Belmarsh

Electronic evidence and the meaning of "original"

Second, the developed countries also have been more vocal and keen on climate mitigation than on adaptation which might imply their huge financial and other practical commitments towards the developing countries. Such mistrust that has developed between the developed and the developing countries can be dispelled with the engaging leadership of the former. However, it is not only the US leadership that is required; China should also lead the developing world as a whole for their own interest.

In Copenhagen one of the contentious issues would be the developed countries' commitment of financial and technological assistance to the developing countries for mitigation and adaptation of climate change. To finance mitigation projects in both developed and developing countries some prescriptions have been made such as capand-trade, clean development mechanism, and harmonized domestic carbon taxes. To these one more could be added, which is to tax the fossil-fuel supplying countries. A proportion of the proceeds from their fossilfuel trade should be used to pay for the damage caused by the global warming. Carbon emissions generated by fossil fuels contribute to 76 per cent of global warming. Such a tax would be an incentive for the suppliers to make more investment in clean energy and be innovative in it. The OPEC could play a significant role in this context.

If the "polluter-pay" principle can be well recognised now, why cannot "emitter-pay" be pushed ahead in an appropriate fashion based on the source factor? This may provide the necessary additional funds for climate mitigation and adaptation projects in the developing world. Both the supplier of the sources of emission and the emitter should bear the burden of the social cost they are causing to the world. Mind you, the heroin supplier and the heroin-addict are equally responsible - both morally and legally - for the social ills they cause.

Above all, as the developed countries expect the developing countries to cut their emissions, they themselves should also do so as exemplars. The developed 
countries' financial and practical assistance for climate change should come with their right, in return, to monitor the developing countries' graduated progress under various schemes depending on the levels of their development towards the reduction of their emissions and adaptation to climate change.

One may not be surprised, however, if the Copenhagen meeting is not fully successful this time round, despite the hopes as many may have cherished because of the great urgency of the matter. There are various complex issues as well as conflict of interests among the nations which might take a while to resolve. The least that the meeting could do is to agree on a broad legal framework involving both developed and developing countries and leave the details for future refinement. In this way the success of the meeting could be seen as a significant building block towards the ultimate goal.

Professor A F M Maniruzzaman

PhD (Cantab); Consultant Editor, Amicus Curiae; Professor of International Law and International Business Law, University of Portsmouth; founding Professor of Law and Director of Research \& Postgraduate Research Degrees, Portsmouth School of Law; Member of two Specialist Groups (Environment \& Human Rights and Energy Law \& Climate Change) of the World Conservation Union (IUCN).

\section{Articles for Amicus Curiae}

Amicus Curiae welcomes contributions, which should be accompanied by the name and contact details of the author. The journal publishes articles on a wide variety of issues, ranging from short pieces of 700-1,200 words and longer articles of 4,000 words of so (the upper limit can be extended where appropriate). Articles should be written in an informal style and without footnotes.

Anyone interested in submitting a piece should email Julian Harris (julian.harris@sas.ac.uk). 